\title{
$\nabla$
}

\section{Cross-sectional descriptive study of topical self-medication in a Hospital Dermatology Department in the State of São Paulo}

\author{
Estudo transversal e descritivo sobre a prática da automedicação tópica em \\ serviço de dermatologia do estado de São Paulo, Brasil
}

\author{
Emerson Henrique Padoveze ${ }^{1}$ \\ Flávia Regina Ferreira ${ }^{3}$
}

\author{
Luiz Fernando Costa Nascimento ${ }^{2}$ \\ Viviane Scarpa da Costa Neves ${ }^{4}$
}

\begin{abstract}
Self-medication involves individuals or their carers administering a medical drug of their own choice for symptomatic relief and in the hope of a "cure", without seeking professional medical advice.The aim of this descriptive cross-sectional study conducted at the Dermatology Department of the Taubaté University Hospital was to identify the occurrence of self-medication for the topical treatment of skin diseases in young people under 18, and to analyze the difficulties encountered in the clinical diagnosis of these individuals. We examined 29 cases of self-medication (from a total of 480 attendances). Although self-medication is a common practice in Brazil our study showed that users were not significantly harmed by it.

Keywords: Pediatrics; Self medication; Skin diseases

Resumo: A automedicação é a forma pela qual o indivíduo ou seus responsáveis decidem, sem avaliação médica, o medicamento e a maneira como irão utilizá-lo para alívio sintomático e "cura". O objetivo deste estudo transversal e descritivo, realizado na Dermatologia do Hospital Universitário de Taubaté, foi identificar a ocorrência da automedicação tópica no tratamento de dermatoses em indivíduos menores de 18 anos, bem como analisar a dificuldade no diagnóstico clínico nesses indivíduos. Serão apresentados 480 atendimentos com 29 casos de automedicação. A prática da automedicação, apesar de frequente em nosso meio, não demonstrou prejuízo importante aos seus usuários neste estudo.

Palavras-chave: Automedicação; Dermatopatias; Pediatria
\end{abstract}

Self-medication is a term used to describe the various ways in which the individuals or those responsible for them decide on which drug to administer for symptomatic relief or "cure", without seeking a professional medical evaluation of their condition. Selfmedication can involve sharing other people's drugs, using leftover prescriptions or failing to use medicines prescribed by professional medical practitioners. ${ }^{1,2}$

In developed countries the prevalence of selfmedication varies between $30 \%$ and $90 \%$. ${ }^{3-6}$ We found a number of positive variables: female gender, being married, family income, educational level and health insurance plans not covering drug costs. ${ }^{3,7,8}$

Few studies have been done in Brazil on this subject. Brazilian literature reveals a rate of self-medication of $53 \%-74 \%$. The most commonly-used drugs are analgesics, antipyretics and NSAIDs. ${ }^{9,10}$

Self-medication in pediatric patients is potentially harmful.

The misuse of topical substances can result in bacterial resistance, hypersensitivity reactions, dependence, withdrawal symptoms etc. Furthermore, the

\footnotetext{
Received on 20.12.2010.

Approved by the Advisory Board and accepted for publication on 13.03.2011

* Work undertaken at Taubaté University Hospital, Taubaté University (HUT- UNITAU), Taubaté (SP), Brazil.

Conflict of interest: None / Conflito de interesse: Nenbum

Financial funding: None / Suporte financeiro: Nenbum

Medical Doctor, Dermatology Intern, Taubaté University Hospital, Taubaté University (HUT-UNITAU), Taubaté (SP), Brazil

PhD, Assistant Professor of Pediatrics, Taubaté University (HUT-UNITAU), Taubaté (SP), Brazil.

Master of Science, III Assistant Professor of Dermatology, Taubaté University (HUT-UNITAU), Taubaté (SP), Brazil

Specialist in Dermatology, Private Practice, São Paulo (SP), Brazil.

(C)2012 by Anais Brasileiros de Dermatologia
} 
temporary relief of symptoms can mask a disease which goes undetected and can progress to a more serious condition.

We undertook a cross-sectional descriptive study of patients treated at the Dermatology Clinic from May 2009 to May 2010, aimed at identifying the occurrence of self-medication in the topical treatment of skin diseases, and analyzing the difficulties encountered in the clinical diagnosis of disease in the affected individuals. Inclusion criteria: patients under 18 years of age who had used a topical medication before specialist consultation.

A standardized questionnaire was applied with a view to evaluating the occurrence of self-medication prior to the consultation. Questions referred to the type of drug used, who indicated the particular substance, why it was decided to use non-prescription medication and whether any changes in the patient's clinical status had been noticed after using the drug.

The sample size was calculated assuming a prevalence of $5 \%$ of individuals who practice self-medication, with accuracy $=2 \%$, significance level $=5 \%$ and a test power $=80 \%$. This produced 456 individuals.

480 individuals under the age of 18 were seen at the dermatology clinic during the study period. Of these, $29(6.0 \%)$ used self-medication.

Of the 29 patients who met the inclusion criteria, 19 (65.5\%) were males and 10 (34.5\%) were females. $23(79.3 \%)$ were white and 6 (20.7\%) non-white. Average school attendance of the patients was 7.4 years, while the average for their fathers was 7.5 years and for their mothers 8.6 years. Average family income of the respondents to the questionaires was around 2.5 times the Brazilian minimum wage.

The reasons given for self-medication were mainly confidence in own abilities $(51.7 \%)$ and difficulty of access to professional medical services (31\%). Both these reasons are interconnected and highlight the difficulty of access to, and the quality of, available health services. Other possible factors include the easy availability of pharmaceutical products and irresponsible advertising drawing attention to the symbolic health-enhancing properties of a particular drug.

Drugs were recommended by family members or friends $(48.0 \%)$, pharmacy employees $(20.0 \%)$ or by doctors from some other branch of medicine. The mass media (TV and magazines) also played an important role (Graph 1). Many drugs are purchased for use by the whole family to save money.

The most commonly-used drugs encountered in our study were: anti-acne preparations (27.5\%), corticosteroids $(20.7 \%)$ and combinations (corticosteroids, antibiotics and antifungals) (20.7\%). Others included moisturizers and barrier creams (Graph 2 ). The high prevalence of acne (particularly facial) in the younger population undermines the self-esteem of individuals and drives them to seek some form of treatment, often encouraged by media advertising which fuels the growing demand for anti-acne products.

The groups of disorders leading to patients seeking help from a dermatologist were: folliculosis (acne), eczema (atopic, nummular, asteatosic and contact), superficial mycoses including tinea pedis and tinea versicolor, pyoderma (impetigo and folliculitis), erythemato-squamous (seborrheic dermatitis and pityriasis rosea) and parasitic conditions (scabies and larva migrans). The most prevalent were eczema and pyoderma, both diseases frequently encountered in this age group $(41.0 \%$ and $31.0 \%$ of cases respectively). The recurrent and self-limited nature of eczema in most cases facilitates the use of nonprescription medications.

Even in those patients where dermatological diagnosis was impeded by prior application of topical medication - 3 cases (9.6\%) - the self-limiting and benign nature of the suspected pathologies (dyshidro-

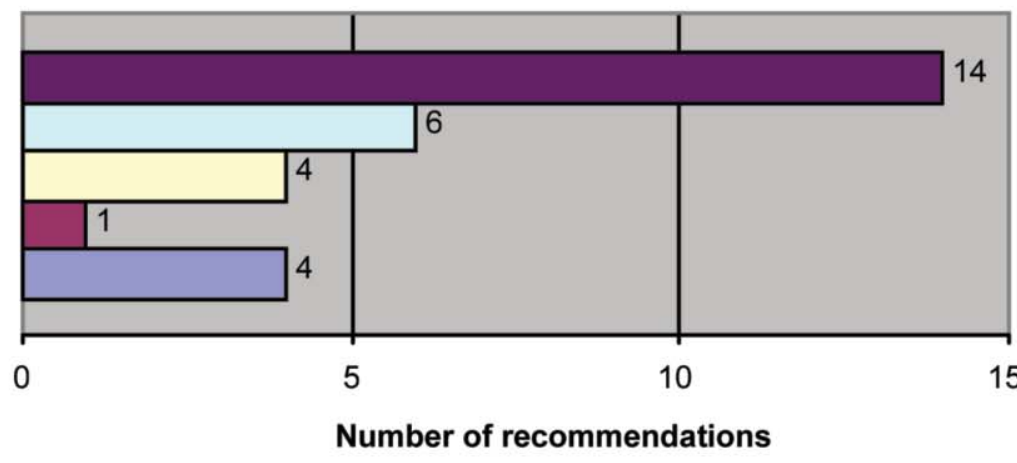

GRAPH 1: Drug indication
Family members/friends

口 Pharmacy employee/

Pharmacist

$\square$ Non-dermatologist doctors

Family members/friends/nondermatologists

Media 


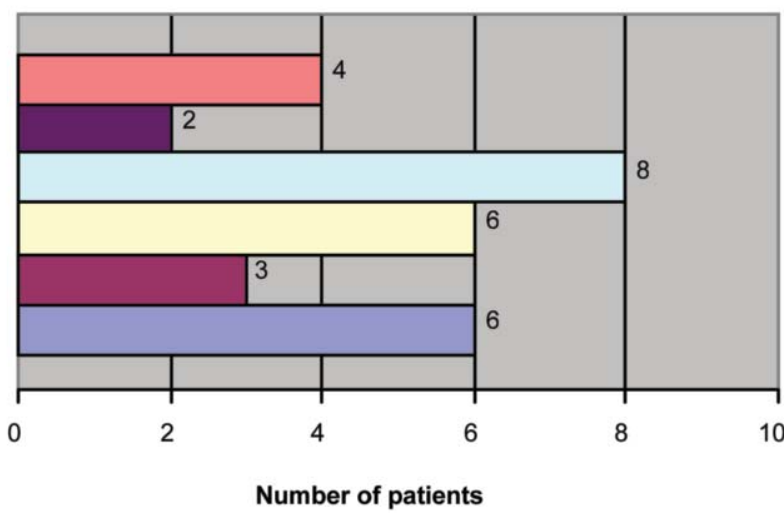

tic and asteatosic eczema and pityriasis versicolor) justified the clinical cure i.e. the drug had little influence on the outcome. Note that we found no case of side effects due to the use of self-medication in our patients. It is however worth mentioning that our study covered only National Health Service (SUS) patients (not private health plan clients) and is therefore somewhat limited in scope due to the lack of data on cases of self-medication by the latter.

Self-medication is common, yet often goes underreported, in Brazil. The fact that some skin diseases are self-limiting and benign encourages selfmedication, with the result that patients frequently do not see the need to seek professional advice from dermatologists.

\section{REFERENCES}

1. Paulo LG, Zanini AC. Automedicação no Brasil. Rev Ass Med Bras. 1988:34:69-75.

2. Arrais PSD, Coelho HLL, Batista MCDS, Carvalho ML, Righi RE, Arnau JM. Perfil da automedicação no Brasil. Rev Saude Publica. 1997;31:71-7.

3. Johnson RE, Pope CR. Health status and social factors in nonprescribed drug use. Med Care. 1983;21:225-33.

4. Lam CLK, Catarivas MG, Munro C, Lauder IJ. Selfmedication among Hong Kong Chinese. Soc Sci Med. 1994;39:1641-7.

5. Francis S VT, Pereira FB, Stephan C, Cordeiro R. Self-medication in children and adolescents. J Pediatr. 2007;83:453-8.

6. Bush PJ, Osterweis M. Pathways to medicine use. J Health Soc Behav. 1978;19:179-89.

7. Segall A. A community survey of self-medication activities. Med Care. 1990;28:301-10.

8. Bush PJ, Rabin DL. Who's using nonprescribed medicines? Med Care. 1976;14:1014-23.

9. Haak H. Padrões de consumo de medicamentos em dois povoados da Bahia (Brasil). Rev Saúde Pública. 1989;23:143-51.

10. Vilarino JF, Soares IC, Silveira CM, Rödel APP, Bortoli R, Lemos RR. Perfil da automedicação em município do sul do Brasil. Rev Saúde Pública. 1998;32:43-9.

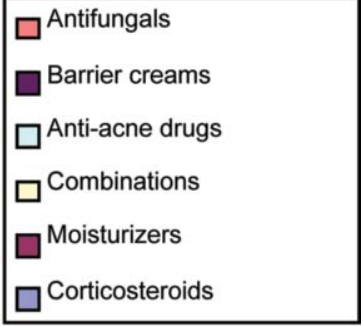

GraPH 2: Drugs used in selfmedication
While our study revealed that self-medication presented no significant impediment to the clinical diagnosis and subsequent treatment of such patients, we believe that it is important that people in our society should be given impartial scientific information on the nonprescription drugs freely on sale, in the hope of reducing massive consumption and the myth of a cure promised by these products. One further important point: people should be encouraged to seek professional medical help from the experts and made aware of the postive advantages to health of a proper medical consultation rather than resorting to self-medication.

\author{
MAILING ADDRESS / ENDEREÇO PARA CORRESPONDÊNCIA : \\ Emerson Henrique Padoveze \\ Avenida Granadeiro Guimarães, 270 - Centro \\ 12100-000 Taubaté, SP, Brazil \\ E-mail:emersonpadoveze@bol.com.br
}

How to cite this article/Como citar este artigo: Padoveze EH, Nascimento LFC, Ferreira FR, Neves VSC. Cross-sectional descriptive study of topical self-medication in a Hospital Dermatology Department in the State of São Paulo. An Bras Dermatol. 2012;87(1):163-5. 